\title{
THE CHALLENGES OF MULTICULTURALISM: A COMPARISON OF SOUTH KOREA, SINGAPORE AND MALAYSIA ${ }^{1}$
}

\author{
Geetha Govindasamy, Er-Win Tan and Park Chang Kyoo
}

\section{Introduction}

The emergence of globalization has resulted in increased movement of peoples of differing ethnic and / or religious extraction across national borders. Although, in many cases, civil society and the media play a role in influencing the development of multiculturalism, this paper limits itself to `state led multiculturalism` in South Korea, Singapore and Malaysia. State led multiculturalism refers to governments that are proactive in establishing, managing and developing a normative framework to govern multiethnic relations that is designed to achieve national integration. In this framework, a government provides a normative standard guide by playing the role of a facilitator in building social cohesion, within its multicultural population, by ensuring some measure of equity in social, economic and political institutions. Whilst most states have attempted to assimilate migrants into the dominant local culture, such attempts have had a mixed record of success in addressing the increasingly multicultural demographic populations. This is evident in the cases of South Korea, Singapore and Malaysia.

Without denying the difficulties in managing a multi-ethnic nation, we reject the notion that multicultural societies are destined for social breakdown, as illustrated in the emerging backlash against multicultural societies in Western Europe. Thus, for instance, former French President criticized the increasing emergence of ethnic ghettoes that failed to integrate into the national community, that if you come to France, you accept to melt into a single community, which is the national community, and if you do not want to accept that, you cannot be welcome in France. We have been too concerned about the identity of the person who was arriving and not enough about the identity of the country that was receiving him. ${ }^{2}$

We argue that multiculturalism means integration, inclusion and a redefined national identity which impacts on nation building and national security. To this end, the paper addresses the question of to what extent and how South Korea can learn from multiculturalism policies and mechanisms embraced by the Singaporean and Malaysian governments. This paper engages with these questions through a comparison of the policy responses of the South Korean, Singaporean and Malaysian governments in integrating multicultural populations.

\footnotetext{
1 This study was sponsored by a grant from the Korea Foundation (2013/2014) in South Korea.

2 'Sarkozy Joins Cameron, Merkel, Condemns Multiculturalism', The New American, 14 February 2011, http:/ / www.thenewamerican.com/world-news/europe/item/8685-sarkozyjoins-cameron-merkel-condemns-multiculturalism, accessed 28 April 2014.
} 


\section{South Korean Multiculturalism}

In recent years, South Korea has been confronted with unprecedented rapid changes in its demographics from a homogenous to an ethnically diverse society (Chun 2008). ${ }^{3}$ For now, South Korea 's foreign population stands at 1.5 million which is 3 percent of its total population (Korea Herald 2013). ${ }^{4}$ Many factors have contributed to a multicultural South Korea. One main reason for this is the aging population and low fertility rate that has created a tension between the need for foreign labour ( especially in so-called 'three-D' jobs - difficult, dangerous, and demanding) and the aspiration of remaining a tanil minjok - one blood nation (Chung \& Kim 2012). ${ }^{5}$ Besides the need for temporary workers in lower levels of the economy, another factor that contributes to the diversity, is delayed marriages or lack of brides in the rural areas, mainly due to South Korean women`s involvement in high-level education and economic activities. The reluctance of women to marry early or beneath their economic status is producing a surge of crossborder brides or international marriages.

One of the features of globalization is women from poorer countries often find spouses from richer countries, it is not surprising then that South Korea`s multicultural society is also a result of marriage migrants, particularly from China, Vietnam and the Philippines, who obtain citizenship by marrying Korean citizens (Freeman 2013). ${ }^{6}$ Within the Korean context, multiculturalism policy has usually been focused on multicultural families and does not include foreign migrant workers who are considered temporary migrants. While multicultural families are under the purview of the Ministry of Gender, Family and Culture, migrant workers are the focus of the Ministry of Labour. According to the Economist, one-seventh of marriages in 2005 were between Koreans and Asians. The number of marriage migrants, mostly women, is around 149,386 (Korea Herald 2013). ${ }^{7}$ In 2009, 44\% of farmers in South Jeolla province took a foreign bride. ${ }^{8}$ Among others, the increase of foreign migrant workers, marriage immigrants and children of international marriages, speaks to the growing necessity for integration of foreigners in Korean society. Given Korea's racial and cultural homogeneity, biases and discrimination against foreigners remain entrenched. ${ }^{9}$ This was reflected in the recent controversy surrounding 'Little Psy', a boy born to a South Korean father and

3 Chun, S. J., 'Multicultural education as a social integration mechanism, in Ewha Womans University (ed.), Globalization and households in East Asia: Policy.

4 'Korea Faces Multiethnic Challenges as Foreign Population Rises to 1.5m,' Korea Herald, 10 June 2013, available at http:/ / www.koreaherald.com/view.php?ud=20130610000871

5 Erin Aeran Chung, Daisy Kim, 'Citizenship and Marriage in a Globalizing World: Multicultural Families, and Monocultural Nationality Laws in Korea and Japan', Indiana Journal of Global Legal Studies, Volume 19, Issue 1, Winter, 2012, p195-219.

6 See review by Andrew J Nathan of Caren Freman`s book entitled, Making and Faking Kinship:Marriage and Labor Migration Between China and South Korea, featured in Foreign Affairs, March/April 2013.

7 Park, Young-bum, 'South Korea: Balancing Labour Demand with Strict Controls', Country Profile, Migration Policy Institute, December 2004, available at http://www.migrationinformation.org/ Profiles/display.cfm?ID=272.

8 'The Flight from Marriage', The Economists, 20 August 2011 (online edition, page number unavailable).

9 'Korean Society Struggles to Embrace Multiculturalism, Jakarta Post, 19 June 2012, available at http://www.thejakartapost.com/news/2012/06/19/korean-society-struggles-embracemulticulturalism.html. 
Vietnamese mother, who, despite the popularity of his impression of Psy's 'Gangnam Style' dance, received a torrent of racial abuse as a 'half-breed' ${ }^{10}$

Given the deeply internalized concept of an ethnically homogenous Korean national identity, the racist backlash against an increasingly multicultural Korean society is not surprising, inasmuch as it underscores the need for the South Korean Government to adopt a more coherent strategy for coping with changing demographics. The government thus redefined immigration and multiculturalism policies by promoting "an open society coexisting with foreigners". ${ }^{11}$ Since 2008, multicultural policies have attempted to improve migrant participation in education, as well as in the social and economic sectors. A series of legislations were enacted but policies are fragmented and uncoordinated as there is no single agency that coordinates the policies. Consequently, monitoring is difficult as too many overlaps exist due to the simultaneous involvement of several ministries.

Kim Choong Soon (2012) observes that discussions of multiculturalism in South Korea focuses on multicultural families rather than on broader social issues. ${ }^{12}$ There are supportive programs for multicultural families and foreign students but not foreign workers who are perceived as short term migrants. Kim Nam Kook notes that the government perceives the nurturing of multicultural families will overcome future problems of labour shortages and low birth rates. ${ }^{13}$ This is a misplaced strategy as migrant workers are essential for the development of the Korean economy, and in some instances, the same migrant workers get married to Korean citizens and become part of the multicultural family.

Furthermore, scholars such as Seol Dong Hoon argue that Korean multiculturalism follows the assimilation model. ${ }^{14}$ The latter is based on the notion that new migrants should abandon their existing national and cultural identity and assimilate into their host nation. Foreign migrants in South Korea face numerous problems from domestic violence to racial discrimination. Inclusiveness is still lacking and policies that help both native Koreans and foreign immigrants to adapt into the society remain underdeveloped. Such demographic realities underscore the necessity of devising policies to create a more inclusionary society that can assist in the integration of migrants, whilst simultaneously persuading native Koreans to accept a country that is multicultural and cosmopolitan in character. Such objectives require that the South Korean eradicate barriers that reduce social exclusion that impedes full participation of migrants into society. In this context, we argue that South Korea can learn from the varied state led multicultural policies of Singapore and Malaysia that celebrates diversity, acknowledges socio-cultural differences, but encourages inclusiveness.

10 "Little PSY" Hwang Min Woo Suffers from Racist Hate Speech, http://www.soompi. com/2013/05/02/little-psy-hwang-min-woo-suffers-from-racist-hate-speech/

11 Kim Nam-Kook, 'Multicultural Challenges in Korea: The Current Stage and a Prospect, International Migration, 12 October 2009, doi: 10.1111/j.1468-2435.2009.00582.x, p 2.

12 Kim, Choong Soon, Voices of Foreign Brides: The Roots and Development of Multiculturalism in Korea, Rowman \& Littlefield, 2012.

13 Kim Nam-Kook, 'Multicultural Challenges in Korea: The Current Stage and a Prospect', International Migration, 12 October 2009, doi: 10.1111/j.1468-2435.2009.00582.x, p2.

14 Seol Dong Hoon, 'Which Multiculturalism: Discourse on the Incorporation of Immigrants into Korean Society, Korea Observer, Winter 2010, Vol. 41, Issue 4, p 605. 


\section{Singaporean and Malaysian Multiculturalism Policies}

Multiculturalism constitutes a defining characteristic of the Singaporean and Malaysian population. Both Singapore and Malaysia share a British colonial past that predominantly saw the bringing of Chinese and Indian labourers as well as professional classes into the Malay heartland. As a result, British Malaya and Singapore emerged as multiethnic, multi-lingual and multi-religious enclaves (see Table 1 as examples of multiethnic population in both countries).

Table 1: Population Statistics of Singapore and Malaysia

\begin{tabular}{|l|l|l|}
\hline & Singapore (2000) & Malaysia (2004) \\
\hline Total population (2013) & $5,460,302$ & $29,628,392$ \\
\hline Malays & $13.9 \%$ & $50.4 \%$ \\
\hline Chinese & $76.8 \%$ & $23.7 \%$ \\
\hline Indians & $7.9 \%$ & $7.1 \%$ \\
\hline Others & $1.4 \%$ & $7.8 \%$ \\
\hline Indigenous & - & $-11 \%$ \\
\hline
\end{tabular}

Source: Central Intelligence Agency, USA, available at https://www.cia.gov/library/publications/theworldfactbook/geos/sn.html

After independence, both states promoted ethnic relations in a myriad of ways. It is reasonable to argue that for both Singapore and Malaysia, nation-building and national unity remains a basic national agenda that is yet to be fully resolved. Basically both governments are driven by fears of any forms of racial conflicts. Hence, it is not surprising that state led multiculturalism governs policies relating to race, language, use of public space and funds in these states. Both the People's Action Party (PAP) of Singapore and Barisan Nasional (Malay for National Front) of Malaysia regulate racial and religious discourse in order to avoid hostilities from emerging between ethnic groups.

There are various conceptions of multiculturalism and as such policies differ from country to country. Both Singaporean and Malaysian multiculturalism policies are mostly similar in that they accept diversity and support ethnic identities within a framework of common laws and shared notion of a national identity. But they are distinctively different in allowing every ethnic group to participate equitably. For Singapore, meritocracy (which is based on talent and merit) is key to political and social cohesion. Individuals are assessed based on their capabilities regardless of class, race or creed. In other words, the system does not discriminate and offers everyone equal opportunity. Multicultural policies differ according to country, even when citizens are given equal rights in the eyes of the law, certain groups may still benefit more than others.

On the other hand, Malaysia practices affirmative action as a national policy. The policy is a result of the unequal economic backgrounds of its multiethnic population. Whilst the unique political and socioeconomic characteristics of Singapore and Malaysia mean that it would be necessary to avoid excessive extrapolation in deriving a model of a successful multicultural society, we nonetheless argue that certain features of the Singaporean and Malaysian models aimed at building a distinct national identity somewhat stands as a qualified success and that they are worth examining and adapting 
to suit the multicultural challenges of South Korea. This is reflected in an examination of four features of multicultural policies in Singapore and Malaysia -basic orientation towards multicultural policies by the state, the promotion of national values, the policy of language pluralism and national curriculum in public schools.

\section{1) Basic Orientation towards Multiculturalism Policies}

On one hand, Singapore opted for a multicultural approach based on seeking harmony between differing ethnic and religious communities. Its multicultural policy reflects the theme of 'unity amidst diversity'. Thus, for instance, even whilst encouraging its component communities to embrace and celebrate their unique cultural heritage, there is strong, nation-wide emphasis on the notion of a shared Singaporean national identity that is based on secular values that transcend communal boundaries. On the other hand, Malaysia practises policies that prioritize the Malay language and providing socioeconomic advantages to the Bumiputera community in return for guaranteed constitutional rights for minorities to practice their religion and cultures. The government fears future instabilities arising out of economic disparity between Bumiputeras and non-Bumiputeras. When unveiling the latest Bumiputera policy, Prime Minister Najib Tun Razak pointed that over $65 \%$ of the country's Bumiputeras, mostly Malays and non-Muslims of Sabah and Sarawak were still economically marginalized. However, he assured the public that this new policy will be carried out without neglecting the non-Bumiputera citizens.

\section{2) National Ideology/Identity/Philosophy}

Living in a multicultural society requires a high level of understanding and respect of those from other cultures. Consequently, fostering greater integration among the various ethnic groups is of paramount importance in multicultural Malaysia and Singapore. To achieve this, both states constructed a national ideology (or sometimes referred to as civic identity or national philosophy) whereby all races and faiths could subscribe to and live by. For example, drawing on the different cultural heritages, among others, Singapore introduced the concept of Shared Values (1991) and Malaysia, the Rukunegara (1970) (see table 2). ${ }^{15}$

\section{Table 2: National Ideology/Values/Philosophy}

\begin{tabular}{|l|l|}
\hline Singapore (Shared values) & Malaysia (Rukunegara) \\
\hline Nation before community and society above self & Belief in God \\
\hline Family as the basic unit of society & Loyalty to King and Country \\
\hline Regard and community support for the individual & Supremacy of the Constitution \\
\hline Consensus instead of contention & The Rule of Law \\
\hline Racial and religious harmony & Good Behaviour and Morality \\
\hline
\end{tabular}

Source: Rukunegara, http:// pmr.penerangan.gov.my/index.php/profil-malaysia/7957-rukun-negara. html, assessed 8 December 2013; Singapore Shared Values, http://eresources.nlb.gov.sg/infopedia/articles/ SIP_542_2004-12-18.html

15 See more at Ministry of Culture, Youth and Sport, Singapore, 14 January 2013, available at http://app.mccy.gov.sg/Newsroom/KeyValuesandPrinciplesforSingapore.aspx\#sthash. Rsbjod5V.dpuf; Center for Public Policy Studies, available at http://www.cpps.org.my/ Resources-@-Rukun_Negara.aspx. 
While Singapore emphasizes the secular nature of the state, Malaysia stresses on its religious identity by promoting Islam as its official religion. Both states use this prevailing national value system to unify a culturally diverse mix of peoples into one, single nation. With the expectation that these values and elements would be practiced by individuals and institutions, both states believed that in time, all communities would develop more distinctively Singaporean or Malaysian characteristics.

Such identifications were expected to inculcate a greater sense of belonging and identity in being a Singaporean or Malaysian, irrespective of race and creed. Further, Singapore also introduced 'unity amidst diversity' aiming to establish social harmony and cohesion. In promoting a common unique Malaysian identity and national unity, Malaysia introduced several concepts which include Bangsa Malaysia (one Malaysian race) and the notion of One Malaysia. Since there are no perfect multicultural models, both Malaysia and Singapore have achieved different degrees of success in integrating their polyglot citizenry. It should be acknowledged that the shaping of a multicultural society that follows a top-down approach is fraught with tensions. As Sudhir Thomas Vadaketh observes,

in Singapore there exists a degree of harmony and integration, but there are deep uncertainties about what Singaporean identity actually means. In Malaysia, by contrast, there is more ethnic and religious strife, often centred on disagreements about how Malay Muslim constitutional pre-eminence should be applied in society. However, even while Malaysians repeatedly re-negotiate this social contract, one might argue that they are more comfortable in their own skin - they have a stronger sense of identity. ${ }^{16}$

\section{3) The Policy of Language Pluralism}

In order to foster equality, promote fairness, and encourage the socialization among different races, both Singapore and Malaysia promote language pluralism in education. ${ }^{17}$ The medium of instruction in Singaporean public schools at all levels is English; this is undertaken in conjunction with the requirement that students take one other language, usually their mother tongue. In the Malaysian education system, Malay has been designated as the national and official language. In addition, English is a compulsory language taught in all Malaysian schools. In most national schools, students are not required but are given opportunities to learn Tamil and Mandarin Chinese. The existence of Tamil and Chinese vernacular schools at the primary level within the national education system, equally protects minority language rights. In short, English and Malay as official languages in Singapore and Malaysia have become key to national unity and racial integration of polyglot societies. Furthermore, the promotion of mother tongue or minority languages in mainstream education in Singapore and Malaysia shows that the state understands the need to protect cultural and linguistic pluralism. Such multicultural policies provide citizens the freedom to maintain their languages and cultures within a socially cohesive framework of shared values.

\footnotetext{
16 Sudhir Thomas Vadaketh, 'The End of Identity?', Institute of Policy Studies, available at http:// ipscommons.sg/index.php/categories/featured/78-the-end-of-identity. Date unavailable.

17 Ministry of Education, Singapore, http://www.moe.gov.sg/, assessed 12 December 2013; Ministry of Education, Malaysiahttp:/ / www.moe.gov.my/, assessed 12 December 2013.
} 


\section{4) National Curriculum}

National curriculums in public institutions of learning play a key role in forging allegiance and national identity in order to fulfill goals of nation-building. Consistent with this aim, Singaporean primary and secondary schools have included Social Studies as a subject that aims to instill national loyalty, patriotism and a sense of belonging. ${ }^{18}$ Accordingly, the curriculum exposes students to their historical roots and their physical and social environment. Despite some variations of emphasis, the Malaysian education system shares similar goals by teaching several subjects like Moral Education, History, Local Studies as well as Civic and Citizenship Education at various levels. ${ }^{19}$ While the Social Studies syllabus emphasizes a sense of loyalty, pride, ideas of equal opportunity and meritocracy, the Malaysian subjects focus on instilling patriotic spirit, the spirit of "we-ness" (semangat kekitaan) and cultivating citizens who are knowledgeable, God fearing, well-behaved and competent. All in all, both sets of national curriculum formulate values that prepare young Singaporeans and Malaysians to become informed, loyal and participative citizens.

\section{What Can South Korea Learn from Singapore and Malaysia?}

Multiculturalism carries a plethora of meanings to different quarters of society. However, for governments, one of the challenges to multiculturalism is to provide opportunities for different groups to maintain cultures while at the same time building a nation in which everyone is included and to which they feel committed to. For this reason, in Singapore and Malaysia, multiculturalism is interrelated with national identity/ ideology/ philosophy and nation building. Being a Singaporean or Malaysian today means that everyone has multiple identities (a national as well as ethnic identity). Both governments continuously pursue policies that meet national needs as well as community needs. The success of these policies is questionable as they are mostly enforced by legal and structural means within a semi authoritative/ paternalistic environment. However, the result so far has shown that both Singapore and Malaysia have successfully contained any major repeats of the inter-communal 1960s riots in both countries.

We have argued here that the quest in forging a successful multicultural nation is a political project led by the state and that without an accommodating, inclusive, and pluralistic society, a multicultural identity will be hard - if not impossible - to create. The state conceives policies with a focus on the nation, common identity and shared values. Consequently, the construction of a national identity, ideology and philosophy that is dynamic and encourages different communities to embrace and celebrate their unique cultural heritage is of equal importance. In addition, the learning of one official language together with mother tongue languages and a national curriculum that emphasizes integration is promoted in order to boost the inculcation of national identities without sacrificing the cultural heritage of minority groups. These policies encourage the development of citizens' appreciation for cultural diversity and promote common denominators in providing opportunities for mixing and accepting a multicultural society. Finding the right policies for South Korea is an important challenge to Seoul.

18 Ministry of Education, Singapore, http://www.moe.gov.sg/education/syllabuses/ humanities/, assessed December 2013.

19 Ministry of Education, Malaysia, assessed December 2013. 
Based on the discussion above, we believe that the salient aspects of Singaporean and Malaysian experiences offer potential for the basis of a coherent long-term strategy for Koreans to adapt to an increasingly diverse demographic. The fact that efforts are being made at policy level indicates that the Korean government is serious in embracing multiculturalism. Though there is much to do, it has done the right thing by first taking the lead in embracing the integration of multicultural families, especially as an official national policy. However several elements need to be improved. Given that many native Koreans continue to identify the myth of tanil minjok as the basis for Korean national identity it is necessary for the South Korean Government to define the terms and rights of political and social membership in society in order to support the new demographic changes.

The majority of Koreans have had few opportunities for interaction with the growing numbers of foreign nationals working and living in their country. Due to fears of erosion of Korea's national identity, the prospect of a multi-ethnic Korea has already led to some calling for restrictions in immigration. Further, evidence indicates that Korea`s assimilationist approach is not working as foreigners constantly face various degrees of discrimination. Policies need to be put in place to encourage native Koreans to embrace migrants as fellow citizens with 'shared values' and a stake in society. If successful, this would enable a changed mindset amongst native Koreans on what it means to be a citizen of a multicultural Korea. If Koreans can be encouraged to move away from an ethnic conceptualization of the Korean nation in favour of 'shared values' espoused by Singapore, such an outcome may lead to the emergence of a nation that is culturally strengthened by a more inclusive, pluralistic society composed of citizens from different ethnic backgrounds.

The other possibility of course is to follow the Malaysian Bumiputera policy whereby affirmative action policies are put in place so that native Koreans enjoy certain privileges in particular sectors so as to reduce the fear of being overwhelmed by migrants. But such a policy can potentially create a stigma that native Koreans are discriminatory towards the migrant population. Hence, the more positive strategy would be to introduce legislation that would allow foreigners to be a part of wider society. This may include, inter alia, legislation that prohibits discriminatory hiring practices that are biased against new migrants and their mixed-race children residing in Korea. This would create a more diverse work environment which would provide opportunities for native Koreans to mix with migrant populations. This can be achieved by the fostering of social capital across different groups.

The South Korean Government's strategy thus far has been reflected in its "First Basic Plan for Immigration Policy 2008-2012", striving for a "world class Korea where foreigners live in harmony with Koreans". ${ }^{20}$ The plan aims to introduce policies which provide "foreigners with the proper environment conducive for their political, economic, social, and cultural participation" ${ }^{21}$ Such a plan could work if the national curriculum is revamped to include multicultural policies so that native Korean and migrants can adapt to new realities. Policies espoused by Singapore and Malaysia, particularly in education where the promotion of a national/ official language as well as encouraging students to learn a second language (preferably their mother tongue) would certainly

20 Ministry of Justice, The First Basic Plan for Immigration Policy: 2008-2012, Kyunggi-do: Ministry of Justice, Republic of Korea, 2008.

21 Ministry of Justice, The First Basic Plan for Immigration Policy: 2008-2012, 2008. 
bring together migrants and ethnic Koreans. Trust between native Koreans and new migrants can built through the promotion of national and regional cultural activities that incorporate the languages of a multicultural Korea. Given time, this may provide increased social space and opportunities for both sides: native Koreans may come to view new migrants as fellow ROK citizens, whilst new migrants are offered a friendly and welcoming environment.

Globalisation has posed an increasing challenge to the notion that national identity should be based on ethnic grounds. In the Korean context, past narratives of national identity have been based on tanil minjok, or the myth of an ethnically homogenous nation descended from a single blood-line. Such a national identity is outdated given that Korea has become an increasingly multicultural society. There is thus a need for South Korea to revise its 'national ideology' (similar to the Shared Values and Rukunegara) in the direction of one that accepts the idea of cultural diversity in order to assist integration between native Koreans and migrants. In time, such a 'national ideology' would serve as a fundamental building block for a redefined Korean nation, and more importantly good citizenship.

\section{Conclusion}

The salient aspects of Singaporean and Malaysian multicultural experiences do offer some basis for a more coherent long term strategy for South Korean policymakers. One of the strongest features of multiculturalism from these countries is the fact that a vision of harmonization (rationalized differently in Singapore and Malaysia) rather than assimilation has been incorporated into the national psyche in adapting to a multicultural environment. Moreover, multiculturalism in Singapore and Malaysia ensures the preservation of the cultural heritage and traditions of different communities. State led, the process of harmonization is based on the promotion of a series of shared common values that is deemed necessary for successful nation building and identity. Until society at large is able to manage the increasing ethnic and cultural diversity present in Korea today, Seoul's role in facilitating immigrants in their efforts to adapt and integrate into Korean society is critical. 
Jurnal EAJIR Bab 3.indd 34 19/09/2014 9:56:43 